\title{
Line Balancing Analysis of Hollow Dakota 1730 Manufacturing Process in PT XYZ
}

\author{
Rachmad Hidayat ${ }^{1}$, Shofi fitrotis Salimah ${ }^{1 *}$, Moh. Jufriyanto ${ }^{2}$, and M.Firman Khaqiqi ${ }^{2}$ \\ ${ }^{1}$ Industrial Department, Engineering Faculty, University of Trunojoyo Madura, Indonesia \\ ${ }^{2}$ Industrial Department, Engineering Faculty, University of Muhammadiyah Gresik, Indonesia
}

\begin{abstract}
The existence of operational balance in each production lines may decrease the idle time; it shows that the productivity is increasing therefore it increases the production rate. The issues existed in the production process of hollow Dakota 1730 in PT. XYZ were 3 departments, from the result of the first observation, there was a bottleneck from each department and each production did not achieve the required target. Therefore, this research would fix the production line. The method used was ranked /positional weight. Based on the data processing by the ranked positional weight method, gained the total of work station in the production process of hollow Dakota 1730 by the number of 2 work stations. From the result of efficiency balancing, gained $62.5 \%$ and balance delay value was $37.5 \%$. it shows that the balance performance between each department increases significantly.
\end{abstract}

Keywords: Productivity, Ranked positional weight, Efficiency balancing, Balance delay, Bottleneck

\section{Introduction}

Most manufacturing companies pay close attention on how to increase productivity and minimize production costs [4];[5]. In addition, in the production process, bottlenecks often occur unavoidably. One of the ways to reduce bottlenecks and increase productivity that needs to be done is to balance the operation of work at each workstation. There have been many studies using various heuristic analytical methods, algorithms and computational simulations [11]-[15]. With the balance of operations in each production line can reduce idle time, this indicates that productivity is increasing so that it can increase the production rate [19];[20];[6].

At present, in the production process of hollow Dakota 1730 at PT. XYZ, there are 3 departments where initial observations indicate there is a bottleneck in each department and in each production did not reach the target specified by the company. Therefore, this research will improve the production line by using one of the line balancing methods, namely Ranked Positional Weight.

Ranked positional weight method is one of the heuristic methods to solve production line problems [7][10]. A research compared algorithmic methods and ranked positional weight in analyzing line balancing [1]. The result shows that the ranking positional weight method is a technique to find out how to synchronize the sorting of work station at a time of limited data availability and the ranking positional weight method is able to represent a more precise output than the algorithm method [1]. At present, in the production process of hollow Dakota 1730 at PT. XYZ, there are 3 departments where initial observations indicate there is a bottleneck in each department and in each production did not reach the target specified by the company. Therefore, this research will improve the production line by using one of the line balancing methods, namely Ranked Positional Weight.

\section{Methods}

The type of data used in this research is primary data. The data is a time-cycle data of the working element production process of the hollow Dakota 1730. Observations are carried out directly at the production process site with a total of 186 observations on each working element. The working element cycle time that will be completed by the ranked positional weight method is the data on the average time of the working element cycle of the hollow Dakota 1730 production process. There are 14 operating elements divided into three stations. The data are as follows: Product Manufacturing Process Stages.

\footnotetext{
*Corresponding author : shofi.fitrotis@trunojoyo.ac.id
} 
Table 1. Working Elements

\begin{tabular}{|c|c|c|c|}
\hline No. & $\begin{array}{c}\text { Product } \\
\text { Manufacturing } \\
\text { Process Stages }\end{array}$ & Operation & Department \\
\hline 1 & Slitter setting & O-1 & $\begin{array}{c}\text { Department } 1 \\
\text { (Setting } \\
\& \text { Cutting) }\end{array}$ \\
\hline 2 & Coil picking & $\mathrm{O}-2$ & $\begin{array}{l}\text { Department } 1 \\
\text { (Cutting) }\end{array}$ \\
\hline 3 & $\begin{array}{l}\text { Opening the coil } \\
\text { packing }\end{array}$ & $\mathrm{O}-3$ & $\begin{array}{c}\text { Department } 1 \\
\text { (Cutting) }\end{array}$ \\
\hline 4 & $\begin{array}{l}\text { Coil get into the } \\
\text { machine }\end{array}$ & $\mathrm{O}-4$ & $\begin{array}{l}\text { Department } 1 \\
\text { (Cutting) }\end{array}$ \\
\hline 5 & $\begin{array}{l}\text { Coil preparation in } \\
\text { the machine }\end{array}$ & O-5 & $\begin{array}{l}\text { Department } 1 \\
\text { (Cutting) }\end{array}$ \\
\hline 6 & $\begin{array}{l}\text { Setting slitter } \\
\text { machine (coil } \\
\text { length and } \\
\text { thickness) }\end{array}$ & O-6 & $\begin{array}{l}\text { Department } 1 \\
\text { (Cutting) }\end{array}$ \\
\hline 7 & $\begin{array}{l}\text { Waiting for the } \\
\text { production process } \\
1 \text { of slitter coil } \\
\text { (material for } \\
\text { hollow Dakota } \\
1730 \text { ) }\end{array}$ & O-7 & $\begin{array}{c}\text { Department } 1 \\
\text { (Cutting) }\end{array}$ \\
\hline 8 & $\begin{array}{l}\text { Transferring the } \\
\text { cut coil, which is } \\
\text { the process of } \\
\text { moving the cut coil } \\
\text { into the Hollow } \\
\text { Dakota } 1730 \\
\text { machine }\end{array}$ & O-8 & $\begin{array}{l}\text { Department } 2 \\
\text { (Production) }\end{array}$ \\
\hline 9 & $\begin{array}{l}\text { Cleaning and } \\
\text { setting the Hollow } \\
\text { Dakota } 1730 \\
\text { machine }\end{array}$ & O-9 & $\begin{array}{l}\text { Department } 2 \\
\text { (Production) }\end{array}$ \\
\hline 10 & $\begin{array}{l}\text { Material } \\
\text { preparation get into } \\
\text { the machine }\end{array}$ & $\mathrm{O}-10$ & $\begin{array}{c}\text { Department } 2 \\
\text { (Production) }\end{array}$ \\
\hline 11 & $\begin{array}{l}\text { Setting hollow } \\
\text { Dakota } 1730 \\
\text { machine }\end{array}$ & O-11 & $\begin{array}{c}\text { Department } 2 \\
\text { (Production) }\end{array}$ \\
\hline 12 & $\begin{array}{l}\text { Checking the } \\
\text { production result } \\
\text { of the hollow } \\
\text { Dakota } 1730\end{array}$ & $\mathrm{O}-12$ & $\begin{array}{l}\text { Department } 2 \\
\text { (Production) }\end{array}$ \\
\hline 13 & $\begin{array}{l}\text { Waiting for the } \\
\text { production process } \\
1 \text { set of hollow } \\
\text { Dakota } 1730\end{array}$ & $\mathrm{O}-13$ & $\begin{array}{c}\text { Department } 2 \\
\text { (Inspection \& } \\
\text { Production) }\end{array}$ \\
\hline 14 & Packing Process & $\mathrm{O}-14$ & $\begin{array}{l}\text { Department } 3 \\
\text { (Packing) }\end{array}$ \\
\hline
\end{tabular}

The following is data on the average cycle time of each work element in the Dakota 1730 hollow production process:
Table 2. Average Time Of Working Element

\begin{tabular}{|c|c|c|}
\hline $\begin{array}{c}\text { Working } \\
\text { elements } \\
\text { (Operation) }\end{array}$ & $\begin{array}{c}\text { Average Time of } \\
\text { Each Operation } \\
\text { (Second) }\end{array}$ & Department \\
\hline Operation 1 & 2004.909 & $\begin{array}{c}\text { Department 1 } \\
\text { (Setting \&Cutting) }\end{array}$ \\
\hline Operation 2 & 106.161 & $\begin{array}{c}\text { Department 1 } \\
\text { (Cutting) }\end{array}$ \\
\hline Operation 3 & 167.333 & $\begin{array}{c}\text { Department 1 } \\
\text { (Cutting) }\end{array}$ \\
\hline Operation 4 & 52.849 & $\begin{array}{c}\text { Department 1 } \\
\text { (Cutting) }\end{array}$ \\
\hline Operation 5 & 135.629 & $\begin{array}{c}\text { Department 1 } \\
\text { (Cutting) }\end{array}$ \\
\hline Operation 6 & 20.112 & $\begin{array}{c}\text { Department 1 } \\
\text { (Cutting) }\end{array}$ \\
\hline Operation 7 & 1407.630 & $\begin{array}{c}\text { Department 1 } \\
\text { (Cutting) }\end{array}$ \\
\hline Operation 8 & 177.994 & $\begin{array}{c}\text { Department 2 } \\
\text { (Production) }\end{array}$ \\
\hline Operation 9 & 658.107 & $\begin{array}{c}\text { Department 2 } \\
\text { (Production) }\end{array}$ \\
\hline Operation 10 & 168.247 & $\begin{array}{c}\text { Department 2 } \\
\text { (Production) }\end{array}$ \\
\hline Operation 11 & 17.408 & $\begin{array}{c}\text { Department 2 } \\
\text { (Production) }\end{array}$ \\
\hline Operation 12 & 12.795 & $\begin{array}{c}\text { Department 2 } \\
\text { (Production) }\end{array}$ \\
\hline Operation 13 & 19.801 & $\begin{array}{l}\text { Department 2 } \\
\text { (Inspection \& } \\
\text { Production) }\end{array}$ \\
\hline
\end{tabular}

Solution using the Ranked Positional Weight (RPW) method [16];[17]:

- Determine work elements based on positional weight for each work element of an operation that has the longest completion time from the beginning of the work to the end of the work element with the lowest completion time.

- Sort the work elements by positional weight in the second step above. The work elements that have the highest positional weight are sorted first.

- Continue by placing work elements that have the highest positional weight to the lowest to each work station.

- If at each work station there is an excess of time, in this case the station time exceeds the cycle time, change or replace the work elements in the work station to the next work station as long as it does not violate the precedence diagram.

- Repeat steps 4 and 5 above until all work elements have been placed into the work station.

In determining the cycle time by taking the longest cycle time [18];[19];[21]. In determining this work station or work station, the following formula can be used [22]:

$$
K \min =\frac{\sum_{i=1}^{k} t i}{C}
$$

Index :

$\sum t i=$ Sum of all operating time 
$\mathrm{t} i=$ Operating time

$\mathrm{C} \quad=$ Cycle Time

$\mathrm{K} \min =$ Minimum number of working stations

After measuring using the RPW method, it is followed by measuring line performance with the following parameters:

Efficiency Balancing is used to find out the balance of the department. To calculate efficiency balancing, you can use the following formula $[23] ;[24]$ :

$$
E_{b}=\frac{\text { Sum of all operating time }}{\text { Total Departemen } x \text { biggest Cycle Time }}
$$

This ballanced delay is used to identify the amount of time lost due to an imperfect balancing process. To find the balanced delay value can be searched with [25] :

$$
\mathrm{d}=1-\mathrm{Eb}
$$

\section{Results}

\subsection{Precedence diagram}

Here's a precedent diagram of the initial production conditions of the hollow Dakota 1730:

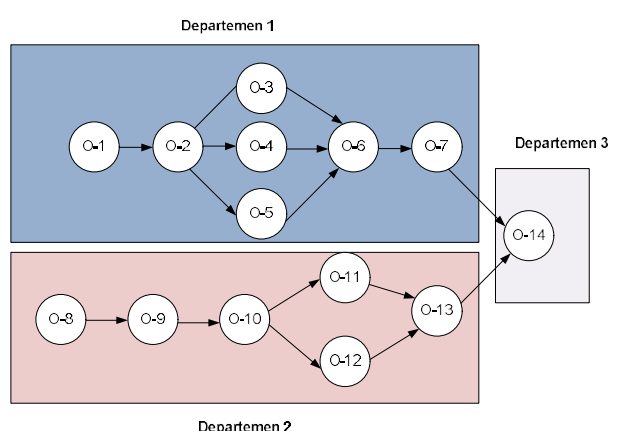

Fig. 1 Precedence diagram

picture $\mathrm{x}$. describes that there are three work station as the starting condition of hollow Dakota 1730 production.

\subsection{Starting Condition Analysis}

The following table shows the starting condition analysis of the hollow Dakota 1730 production in the cycle time determination:

\begin{tabular}{|c|c|c|c|}
\hline Department & $\begin{array}{c}\text { Work } \\
\text { Element } \\
\text { (Operation) }\end{array}$ & $\begin{array}{c}\text { Total of } \\
\text { Work } \\
\text { Station } \\
\text { Cycle Time } \\
\end{array}$ & Biggest CT \\
\hline \multirow{5}{*}{1} & $1^{\text {st }}$ operation & \multirow{5}{*}{3894.623} & \multirow{5}{*}{3894.623} \\
\hline & $\begin{array}{l}2^{\text {nd }} \\
\text { operation }\end{array}$ & & \\
\hline & $3^{\text {rd }}$ operation & & \\
\hline & $4^{\text {th }}$ operation & & \\
\hline & $5^{\text {th }}$ operation & & \\
\hline
\end{tabular}

Table 3. Cycle Time Determination

\begin{tabular}{|c|c|c|}
\hline & $6^{\text {th }}$ operation & \\
\hline & $7^{\text {th }}$ operation & \\
\hline \multirow{6}{*}{2} & $8^{\text {th }}$ operation & \multirow{6}{*}{1054.352} \\
\hline & $9^{\text {th }}$ operation & \\
\hline & $\begin{array}{l}10^{\text {th }} \\
\text { operation }\end{array}$ & \\
\hline & $\begin{array}{l}11^{\text {th }} \\
\text { operation }\end{array}$ & \\
\hline & $\begin{array}{l}12^{\text {th }} \\
\text { operation }\end{array}$ & \\
\hline & $\begin{array}{l}13^{\text {th }} \\
\text { operation }\end{array}$ & \\
\hline 3 & $\begin{array}{l}14^{\text {th }} \\
\text { operation }\end{array}$ & 330.382 \\
\hline
\end{tabular}

From the table, the biggest cycle time in the starting condition analysis is 3894.623 seconds.

\subsection{The Determination of Efficiency Balancing}

The calculation result of efficiency balancing stated below:

$E_{b}=\frac{5279.357}{3 \times 3894.623}=0.45=45 \%$

Based on the efficiency balancing calculation result, it can be known that the production line balancing hollow Dakota 1730 is $45 \%$.

\subsection{The Determination of Balance Delay Value}

The result of balance delay value calculation stated below:

$\mathrm{d}=1-\mathrm{E}_{\mathrm{b}}=1-0.45=0.55=55 \%$

based on the balance delay calculation, the total of time loss due to the imbalance line between each department of hollow Dakota production process is $55 \%$.

\subsection{The Solution of RPW Method}

\subsubsection{Determination of positional weight value :}

The evaluation table of positional weight of each work operation element stated below

\begin{tabular}{|c|c|c|c|}
\hline $\begin{array}{c}\text { Work } \\
\text { Element }\end{array}$ & Positional Weight & $\begin{array}{c}\text { Total } \\
\text { (seconds) }\end{array}$ & Rank \\
\hline $\begin{array}{c}1^{\text {st }} \\
\text { Operation }\end{array}$ & $\begin{array}{c}2004.909+ \\
106.161+167.333 \\
+52.849+ \\
135.629+20.112 \\
+1407.630+ \\
330.382\end{array}$ & 4225.005 & 1 \\
\hline $\begin{array}{c}2^{\text {nd }} \\
\text { Operation }\end{array}$ & $\begin{array}{c}106.161+167.333 \\
+52,849+ \\
135.629+20.112 \\
+1407.63+ \\
330.382 \\
\end{array}$ & 2220.096 & 2 \\
\hline
\end{tabular}

Table 4. Determination of positional weight value 


\begin{tabular}{|c|c|c|c|}
\hline $\begin{array}{c}3^{\text {rd }} \\
\text { Operation }\end{array}$ & $\begin{array}{c}167.333+135.629 \\
+20.112+ \\
1407.630+ \\
330.382\end{array}$ & 1925.457 & 3 \\
\hline $\begin{array}{c}4^{\text {th }} \\
\text { Operation }\end{array}$ & $\begin{array}{c}135.629+20.112 \\
+1407,630+ \\
330,382 \\
\end{array}$ & 1893.753 & 4 \\
\hline $\begin{array}{c}5^{\text {th }} \\
\text { Operation }\end{array}$ & $\begin{array}{c}20.112+1407.630 \\
+330,382\end{array}$ & 1758.124 & 5 \\
\hline $\begin{array}{c}\mathbf{6}^{\text {th }} \\
\text { Operation }\end{array}$ & $\begin{array}{c}1407.630+ \\
330.382\end{array}$ & 1738.012 & 6 \\
\hline $\begin{array}{c}7^{\text {th }} \\
\text { Operation }\end{array}$ & $\begin{array}{c}177.994 \\
+658.107+ \\
168.247+17.408 \\
+12.795+19.801 \\
+330.382\end{array}$ & 1384.734 & 7 \\
\hline $\begin{array}{c}\mathbf{8}^{\text {th }} \\
\text { Operation }\end{array}$ & $\begin{array}{c}658.107+ \\
168.247+17.408 \\
+12.795+19.801 \\
+330.382\end{array}$ & 1206.740 & 8 \\
\hline $\begin{array}{c}9^{\text {th }} \\
\text { Operation } \\
\end{array}$ & $\begin{array}{l}52.849+20.112+ \\
177.994+330.382 \\
\end{array}$ & 581.337 & 9 \\
\hline $\begin{array}{c}10^{\text {th }} \\
\text { Operation }\end{array}$ & $\begin{array}{c}+168.247+17.408 \\
+12.795+19.801 \\
+330.382\end{array}$ & 548.633 & 10 \\
\hline $\begin{array}{c}\text { 11th } \\
\text { Operation }\end{array}$ & $\begin{array}{l}17.408+12.795+ \\
19.801+330.382 \\
\end{array}$ & 367.591 & 11 \\
\hline $\begin{array}{c}12^{\text {th }} \\
\text { Operation }\end{array}$ & $\begin{array}{l}12.795+19.801 \\
\quad+330.382\end{array}$ & 362.9784 & 12 \\
\hline $\begin{array}{c}13^{\text {th }} \\
\text { Operation }\end{array}$ & $19.801+330.382$ & 350.183 & 13 \\
\hline $\begin{array}{c}14^{\text {th }} \\
\text { Operation }\end{array}$ & 330,3817 & 330.382 & 14 \\
\hline
\end{tabular}

From the table above, the positional weight value gained obtained from the connected work operation element. For instance, the $1^{\text {st }}$ work operation element connected with the $1,2,3,4,5,6,7,14$ element therefore the positional weight value obtained is 4225.05 seconds.

\subsubsection{Determination of cycle time}

The determination of cycle time uses the biggest cycle time. The result shows:

Table 5. Determination of biggest CT

\begin{tabular}{|c|c|c|c|}
\hline Department & $\begin{array}{c}\text { Work } \\
\text { Element } \\
\text { (Operation) }\end{array}$ & $\begin{array}{c}\text { Total of Cycle } \\
\text { Time Work } \\
\text { Station }\end{array}$ & $\begin{array}{c}\text { Biggest } \\
\text { CT }\end{array}$ \\
\hline \multirow{6}{*}{1} & $1^{\text {st }}$ Operation & \multirow{6}{*}{3894.623} & \multirow{6}{*}{3894.623} \\
\hline & $2^{\text {nd }}$ Operation & & \\
\hline & $3^{\text {rd }}$ Operation & & \\
\hline & $4^{\text {th }}$ Operation & & \\
\hline & $5^{\text {th }}$ Operation & & \\
\hline & $6^{\text {th }}$ Operation & & \\
\hline
\end{tabular}

\begin{tabular}{|c|c|c|}
\hline & $7^{\text {th }}$ Operation & \\
\hline \multirow{7}{*}{2} & $8^{\text {th }}$ Operation & \multirow{7}{*}{1384.734} \\
\hline & $9^{\text {th }}$ Operation & \\
\hline & $10^{\text {th }}$ Operation & \\
\hline & $11^{\text {th }}$ Operation & \\
\hline & $12^{\text {th }}$ Operation & \\
\hline & $13^{\text {th }}$ Operation & \\
\hline & $14^{\text {th }}$ Operation & \\
\hline
\end{tabular}

From the table, the biggest cycle time is 3894.62 seconds in the $1^{\text {st }}$ work station.

\subsubsection{Determination of Efficiency balancing}

The result of efficiency balancing calculation stated below:

$E_{b}=\frac{5279.357}{2 \times 3894.623}=0.625=62.5 \%$

From the result of efficiency balancing calculation, the production line balancing of hollow Dakota 1730 is $62.5 \%$.

\subsubsection{Determination of balance delay value}

The result of balance delay value calculation stated below:

$\mathrm{d}=1-\mathrm{Eb}=1-0.625=0.375=37.5 \%$.

from the result of balance delay calculation, the total of time loss due to the imbalance line between each department of hollow Dakota 1730 production process is $37.5 \%$

based on the result, there could be comparison between line performance hollow Dakota 1730 production process as follows:

Table 6. Comparison line performance

\begin{tabular}{|l|l|l|}
\hline Indicators & Starting condition & RPW \\
\hline Work station total & 3 & 2 \\
\hline Efficiency balancing & $45 \%$ & $62.5 \%$ \\
\hline Balance delay & $55 \%$ & $37.5 \%$ \\
\hline
\end{tabular}

Based on the comparison above, the idea of fixed-line balancing between each work department by RPW method obtained a better result than the previous condition. It was measured by the parameter value which increase significantly.

\section{Conclusion}

Based on the data processing, the total of work station by RPW method obtained 2 work stations. The parameter result increase significantly from the previous condition, which the efficiency balancing of RPW method is $62.5 \%$ bigger than the previous one. Total of 
time loss also decreases, which affect positively into the balance between each department. The further research is expected to continue the comparison by the other line balancing method. Furthermore, it is possible to measure the cost to obtain the significant cost for each work operation element.

\section{References}

[1] K. Nahar, A. Habib, A. A. Nayon, and M. Hossain, "Assembly Line Balancing Using ACO Algorithm and RPW Method: A Comparative Case Study," vol. 6, no. 3, pp. 1324, (2018).

[2] E. G. Kalaycilar, M. Azizollu, and S. Yeralan, "A disassembly line balancing problem with fixed number of workstations," Eur. J. Oper. Res., vol. 249, no. 2, pp. 592-604, (2016), doi: 10.1016/j.ejor.2015.09.004.

[3] S. R. Ashraf, "Mixed Model Assembly Line Balancing By Using of Sub-Assembly Mixed Model Assembly Line Balancing By Using of Sub-Assembly Parallel Shop," no. February, pp. 93-98, (2017).

[4] A. N. Adnan, N. A. Arbaai, and A. Ismail, "Improvement of overall efficiency of production line by using line balancing," $A R P N$ J. Eng. Appl. Sci., vol. 11, no. 12, pp. 77527758, (2016).

[5] P. Saurabh Jha and M. S. Khan, "An experimental study on the automotive production line using assembly line balancing techniques," Int. J. Mech. Eng. Technol., vol. 8, no. 3, pp. 22-33, (2017).

[6] R. Ginting and A. Lumongga Nst, "Optimizing Production Line Using the Rank Positional Weight (RPW) Method at PT. X," IOP Conf. Ser. Mater. Sci. Eng., vol. 1003, no. 1, pp. 0-8, (2020), doi: $\quad 10.1088 / 1757-$ 899X/1003/1/012034.

[7] M. Mengistu, "Line Balancing Techniques for Productivity Improvement," Int. J. Mech. Ind. Technol., vol. 7, no. 1, pp. 89-104, (2019), [Online].Available:https://www.researchgate.n et/publication/333310098_Line_Balancing_Te chniques_for_Productivity_Improvement.

[8] S. Nallusamy and V. Saravanan, "Enhancement of overall output in a small scale industry through VSM, line balancing and work standardization," Int. J. Eng. Res. Africa, vol. 26, pp. 176-183, (2016), doi: 10.4028/www.scientific.net/JERA.26.176.

[9] J. M. Nilakantan and S. G. Ponnambalam, "Robotic U-shaped assembly line balancing using particle swarm optimization," Eng. Optim., vol. 48, no. 2, pp. 231-252, (2016), doi: 10.1080/0305215X.2014.998664.

[10] T. Ahmed, N. Sakib, R. M. Hridoy, and A. T. Shams, "Application of Line Balancing Heuristics for Achieving an Effective Layout: A Case Study," vol. 9, no. 2, pp. 114-129, (2020), doi: 10.22105/riej.2020.234612.1134.
[11] M. Jamil and N. M. Razali, "Simulation of Assembly Line Balancing in Automotive Component Manufacturing," IOP Conf. Ser. Mater. Sci. Eng., vol. 114, no. 1, (2016), doi: 10.1088/1757-899X/114/1/012049.

[12] I. Siregar, "Application of ranked positional weights method in springbed production line balancing," IOP Conf. Ser. Mater. Sci. Eng., vol. 801, no. 1, pp. 5-11, (2020), doi: 10.1088/1757-899X/801/1/012098.

[13] G. Kumar, "an Optimal Balancing of Assembly Line Using Rpw," Int. J. Eng. Res. Adv. Technol., no. 01, pp. 469-475, (2016).

[14] A. Sawal and A. J. Hamzah, "Application of line balancing using the heuristic method to equalize the production line at PT.Bogatama Marinusa Makassar," IOP Conf. Ser. Mater. Sci. Eng., vol. $\mathbf{8 8 5}$, no. 1, (2020), doi: 10.1088/1757$899 X / 885 / 1 / 012035$

[15] H. Sime, P. Jana, and D. Panghal, "Feasibility of using simulation technique for line balancing in apparel industry," Procedia Manuf., vol. 30, pp. 300-307, (2019), doi: 10.1016/j.promfg.2019.02.043.

[16] E. CAN and A. ÖNER, "Analysis and balancing of assembly line in a machine molding factory," Int. Adv. Res. Eng. J., vol. 5, no. 1, pp. 87-96, (2021), doi: 10.35860/iarej.772678.

[17] N. T. Lam, L. M. Toi, V. T. T. Tuyen, and D. N. Hien, "Lean Line Balancing for an Electronics Assembly Line," Procedia CIRP, vol. 40, no. 1, pp. 437-442, (2016), doi: 10.1016/j.procir.2016.01.089.

[18] S. Ariyanti, M. Rifa'i Azhar, and M. Sobron Yamin Lubis, "Assembly line balancing with the yamazumi method," IOP Conf. Ser. Mater. Sci. Eng., vol. 1007, no. 1, (2020), doi: 10.1088/1757-899X/1007/1/012078.

[19] M. S. Khan and P. Saurabh Jha, "Evaluation of standard time with the application of rank positional weighted method in the production line," Int. J. Mech. Prod. Eng. Res. Dev., vol. 7, no. 2, pp. 73-80, (2017).

[20] S. Alif and B. Aribowo, "Line Balancing Application Analysis of Generator Manufacturing Process in DPG Inc.," IOP Conf. Ser. Mater. Sci. Eng., vol. 528, no. 1, pp. 0-8, (2019), doi: 10.1088/1757-899X/528/1/012057.

[21] M. S. Islam, S. Sarker, and M. Parvez, "Production Efficiency Improvement by Using \&lt;i\&gt;Tecnomatix\&lt;/i\&gt; Simulation Software and RPWM Line Balancing Technique: A Case Study," Am. J. Ind. Bus. Manag., vol. 09, no. 04, pp. 809-820, (2019), doi: 10.4236/ajibm.2019.94054.

[22] Y. Li, H. Wang, and Z. Yang, "Type II assembly line balancing problem with multi-operators," Neural Comput. Appl., vol. 31, pp. 347-357, (2019), doi: 10.1007/s00521-018-3834-1.

[23] I. S. Fahin and N. Banuwati, "Reducing Work Overtime in Production Line by Comparing Two Heuristic Line Balancing Method: Case Study of Beam Comp Stering Hanger at PT. 
Metindo Era Sakti," IOP Conf. Ser. Mater. Sci. Eng., vol. 453, no. 1, (2018), doi: 10.1088/1757899X/453/1/012049.

[24] Buchari, U. Tarigan, and M. B. Ambarita, "Production layout improvement by using line balancing and Systematic Layout Planning (SLP) at PT. XYZ," IOP Conf. Ser. Mater. Sci. Eng., vol.309, no. 1, (2018), doi: 10.1088/1757899X/309/1/012116.

[25] N. A. Bakar, M. F. Ramli, M. Z. Zakaria, T. C. Sin, and H. Masran, "Minimization of Bottleneck and Workstations for Assembly Line Balancing Problem in Power Transformer Manufacturing Using Heuristics," 2018 IEEE 5th Int. Conf. Smart Instrumentation, Meas. Appl. ICSIMA 2018, no. November, pp. 1-5, (2019), doi: 10.1109/ICSIMA.2018.8688780. 